\title{
URBAN HERITAGE MANAGEMENT: PLANNING WITH HISTORY - A REVIEW
}

\section{Dragoş DASCĂLU}

Technical University, Cluj-Napoca, Faculty of Architecture and Urban Planning, ROMANIA

sddascalu@yahoo.com

Urban Heritage Management: Planning with History/ Anna Maria COLAVITTI; Springer International Publishing, Cham, 2018, XXII, 153 p.

\section{INTRODUCTION}

Through its stability, continuation of use, the visible and tangible superpositions of historical layers, reuse of historical elements, continuous reframing of meaning and by both accumulation and selection, the city centre is (and arguably always was) a source of identity for communities and individuals. This historical superposition of layers (formal, social, economic, political, etc.) has to be studied and deciphered when dealing with an urban planning project. How do we

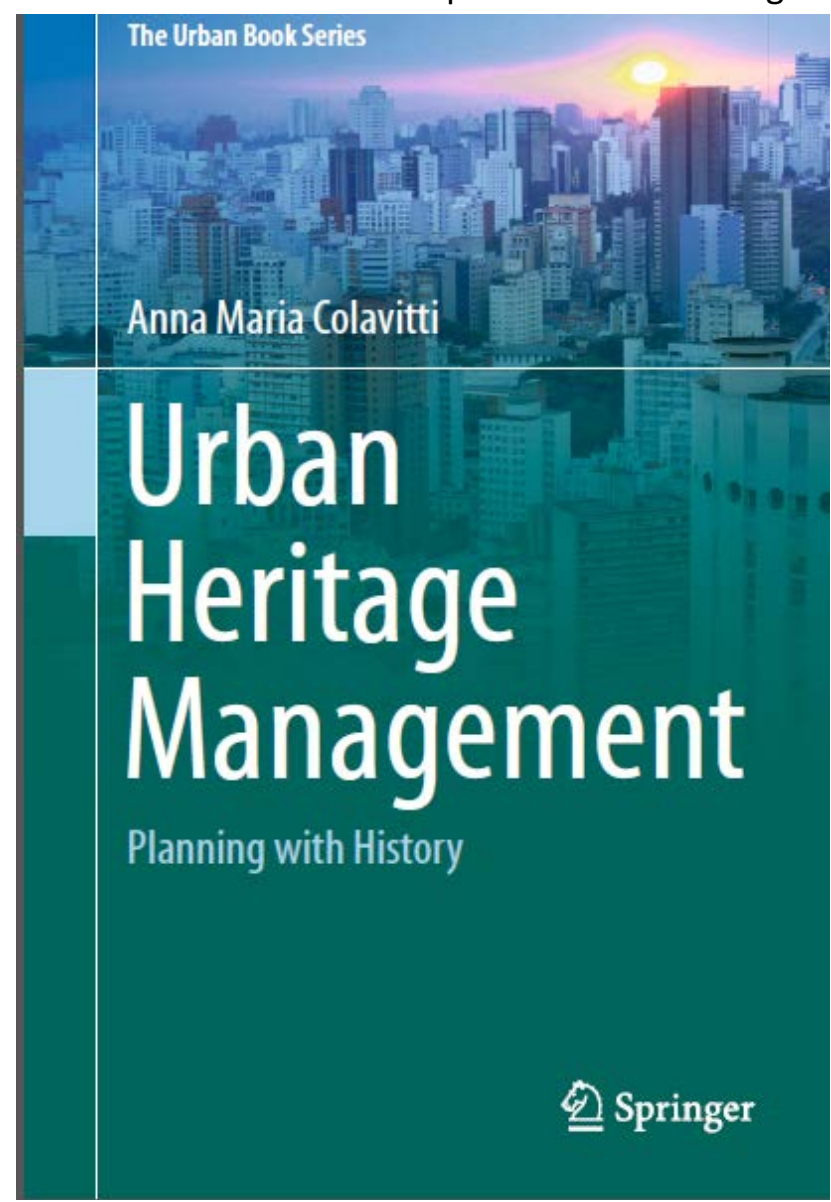
acknowledge, interpret and use as a tool in the urban planning process all the layers that form what we define the cultural heritage of a place? How do we deal with areas with archaeological traces, especially when they are overlapping with the subsequent layers of the city up to the present day? How do we integrate all these layers in such a way that they are protected and preserved but enjoyed and used as well?

More often than not, planners are in the situation of dealing only with a limited number of aspects of the site they plan to transform, thus greatly limiting their range of action - be it strict conservation and museification of a place, or a reinterpretation of the memory of a certain place "without comparing it with the cultural and social needs of the contemporary city and territory" (Colavitti, 2018, p. xix). This approach is the product of an entire tradition of urban planning characterized by segmentation, strict zonification, clarity 
above all. In this sense, cultural heritage and what is considered to be a monument is extracted from its context, expressed and highlighted as a singular object, an exception, a single act of genius, thus ignoring the general cultural context at the time of its creation, the multiple layers added in time and the possible relation to the present urban site.

In this book, Urban Heritage Management: Planning with History, Anna Maria Colavitti lays the groundwork for a multidisciplinary approach and method in dealing with the planning and management of urban heritage sites, based on her experience as consultant for the Framework Plan for the Historical Centre Recovery of Cagliari. Starting from the evident fact that the city is multi-layered, she proposes a topographic method in revealing these layers (as described in the book, a method that helps to analyse the consequences of the juxtaposition of a monument in a territory). The idea is to understand the context and to look at cultural heritage as a cultural good, with a definitive role in the establishment and acknowledgement of collective identities of different communities.

\section{PERSPECTIVES}

The book is structured into five chapters.

The first chapter presents different historical and contemporary visions in which the city, the environment, the landscape, monuments and/or urban heritage, in general, are viewed through a wider perspective, bringing together a multitude of layers. The discussion starts with Ancient Greece and Rome (where the idea of beauty as an imitation of nature-mimesis - was reflecting not only upon aesthetics, but also upon ethics and politics). It continues with the Middle Ages and the Renaissance, and the beginning of the industrial era (with a focus on the birth of the idea of heritage, monument and cultural good and the amount in which they reflect more than strict physical and aesthetic values and in which urban centres are carriers of a multitude of layers including cultural and social values). For the present, the author discusses those theories, laws and codes, which use a multi-layered system of thought concerning the city and its heritage (both physical space and social, anthropological, symbolic, economic aspects).

The second and third chapters lay down the conceptual and methodological approach of the book. Cities have historically been the scene of constant reuse and reinterpretations of the built form. Therefore, the interpretation of urban heritage, city centres, the city itself and of its relation to the territory needs a multi-layered system. This system is based on several methods such as: the stratigraphic method (a method used in archaeology in which the city is the superposition of multiple historical strata and their study must take each of these layers individually and understand how they were formed), the need for the study of context (the relationship between study subject and its environment, as for example between the city and its rural or natural surroundings), and the topographic method (the study of the changes in urban form and their relationship with context). The idea is to extract values and meaning from various strata (though documents and narratives) that can be transferred and imbued into the new plans. The transformation of heritage into a cultural good - a good to be preserved for sure, but also consumed - integrated into the new plans is explained: "the need of combining conservation and development, through the recovery and requalification of the historical city and its territory, does not only require the experimentation of new forms of building and representation of the knowledge, but also the ability to define and manage innovative plans and sustainable hypothesis of reuse based on the knowledge of context and environment" (Colavitti, 2018, p. 72). 
The fourth chapter thoroughly presents the successive laws which have defined the concept of cultural good, from the 1462 Pope Pius II's Bull "Cum alman nostram Urbem" to the current Cultural Heritage and Landscape Code.

The fifth chapter is a case study of the Framework Plan for Historical Centre Recovery of Cagliari, in which the author was directly involved as a consultant. The multi-layered analysis of the environmental history, urban sociology, and the historical morphological analysis based on the archaeology of the pre-existences and on the historical topography were keys to the development of new regulations for Cagliari's city centre. Identifying places of (historical) meaning, connecting them, exposing them and making them usable to the public, and relating them to current places of meaning and current uses were key in this holistic approach to city planning. However, the research and implementation of a plan is only the beginning: "The biggest problem then becomes the choice of tools the urban development plan can use in order to protect and enhance the hidden heritage and, so far, the most appropriate tool appears to be the planning regulation" (Colavitti, 2018, p. 132).

\section{CONCLUSIONS}

Today, both professionals and the public are more conscious of the diversity and complexity of urban situations. Therefore, we agree with the author when she writes: "One of the most interesting aspects of the modern city concerns the cultural sustainability of the actions to undertake in the urban space, in terms of economic sustainability, protection and enhancement of the local environmental and cultural resources and social equity" (Colavitti, 2018, p. 122). This leads to the need for a multidisciplinary, holistic approach to urban planning. There is nothing new in this regard - for a while now, this has become a norm in most parts of Europe. However, in dealing with historical sites, especially those with valuable archaeological finds, it is hard to integrate all the information, as they refer to multiple, superimposed layers.

The historical analysis of laws and regulations and the description of the importance of new methodologies in dealing with heritage sites are the most consistent parts of the book. However, the case study description is somewhat limited and does not go into a lot of detail regarding how decisions were taken, how the risk maps looked like and how they informed decision, and other more in detail aspects of the work carried out in Cagliari.

The book opens up the discussion of the role of heritage sites in everydayurban situations and on how to introduce these new perspectives into urban regulations. One of the mostintriguing parts of the book is the fact that it shows the intricate process through which this new perspective on heritage was transposed into appliable urban regulations. This connection is rarely discussed and known. But the mostimportant contribution of Anna Maria Colavitti's book to the issue of dealing with urban planning of historical sites (and especially archaeological sites) is the introduction into an easily applicable method which analyses all these layers (the analysis of context, topographic method and stratigraphic method). This method aims not only to conserve and exhibit the various layers, but also to make them usable as a part of everyday life, to open up these previously isolated sites, thus proposing an anti-monumental approach to heritage.

\section{REFERENCES}

COLAVITTI, A.M. (2018). Urban Heritage Management: Planning with History. Cham: Springer. 